Yayın Geliş Tarihi: $\quad 01.11 .2017$

Yayın Kabul Tarihi: 12.12 .2017

Online Yayın Tarihi: 20.04.2018

\title{
Impact of Social Media Usage Activities on Brand Awareness of Young Consumers
} Syed Ikram AKBAR ${ }^{1}$

\begin{abstract}
Social media, an inevitable tool of today's communication world, is becoming an inevitable communication channel for businesses too. Due to its structure allowing direct communication between the company and its customers and its superiority over traditional communication channels, it is being used more and more by several companies. Continuous increment in the use of social media tools has made the impact of new generation communication tools on brand awareness very important. For this reason, the effect of Facebook, which is one of the most used social media tools in the researches (or literature), on the brand awareness of the companies is examined. It has been determined that social media can make meaningful effects on brand awareness in the research conducted on young consumers in Izmir region. Regression analysis illustrates that Facebook is responsible for $34 \%$ of brand awareness. Consequently, it is considered that the more intensive and effective use of the advantages derived from the social media tools can provide significant advantages in creating brand awareness, and this should be the subject of further research.
\end{abstract}

Keywords: Social Media Use Intensity (SMUI), Social Integration and Emotional Connection (SIEC), Integration into Social Routines (ISR), Brand Awareness (BA).

JEL Classification Codes: M31, M39.

$\ddot{O} z$

Günümüz iletişim dünyasının vazgeçilmez bir aracı olan sosyal medya, işletmeler için de vazgeçilmez bir iletişim kanalı haline gelmektedir. Firma ve müşterileri arasında doğrudan iletişime olanak veren yapısı ve geleneksel iletişim kanallarına göre üstünlükleri nedeniyle firmalar tarafindan giderek daha fazla kullanılmaktadır. Sosyal medya araçlarının giderek artan kullanımı, bu yeni nesil iletişim araçlarının marka bilinirliğine etkisi önemli hale getirmektedir. Bu nedenle araştırmada sosyal medya araçlarından en yoğun kullanılanlardan biri olan Facebook'un, firmaların marka bilinirliğine etkisi incelenmiştir. İzmir bölgesinde genç tüketiciler üzerinde yapılan araştırmada sosyal medyanın, marka bilinirliği üzerinde anlamlı etkiler yapabildiği tespit edilmiştir. Yapılan regresyon analizi, Facebook'un marka bilinirliğinin \% 34'sünden sorumlu olabildiğini göstermektedir. Dolayısıly işletmelerin sosyal medya araçlarından kaynaklanan avantajları daha yoğun ve etkili olarak kullanmalarının, marka bilinirliği oluşturma konusunda önemli avantajlar săglayabileceği ve bu konunun daha detaylı araştırmalara da konu olması gerektiği düşünülmektedir.

Anahtar Kelimeler: Sosyal Medya Kullanım Düzeyi, Sosyal Entegrasyon ve Duygusal Bağlanma; Sosyal Rutinlere Bă̆lanma, Marka Bilinirliği.

JEL Sinıflandırma Kodları: M31, M39.

${ }^{1}$ Yüksek Lisans Öğrencisi, Dokuz Eylül Üniversitesi, Sosyal Bilimler Enstitüsü, İşletme Anabilim Dal, syedikramakbar@hotmail.com

${ }^{2}$ Doç. Dr., Dokuz Eylül Üniversitesi, İktisadi ve İdari Bilimler Fakültesi, İşletme Bölümü, Üretim Yönetimi ve Pazarlama Anabilim Dalı, engin.ozgul@deu.edu.tr 


\section{INTRODUCTION}

\section{S.I.AKBAR - E.ÖZGÜL}

The era of BBC and The Times has changed because we no longer depend solely on them for source of information. This is a world where people are directly engaged social media and have become media themselves. People now share their thoughts, ideas, insights, perspectives and opinions through various types of online services including images, text, audio or video. The upsurge of social media has fascinated many businesses towards itself.

Brennan and Schafer (2010) discussed in their study that now it has become everyday matter that traditional media like New York Times, USA Today or The Wall Street Journal headlines a story about social media. Social media had astonishing growth in the past 12 months. Twitter, YouTube, Facebook and other social media websites have continuous growth from the number of user perspective.

Social media has become the novel trend of this business era. It is the intermediate, which outshines the conventional intermediary and connects the companies directly with the consumers. This is the reason that whether it be giants like IBM and Starbucks or local burger shop; almost every business in this world is referring towards social media marketing. A few years ago, businesses were abstruse about social media networks. However, nowadays, companies have comprehended the importance of this new medium of marketing which is rapidly growing. The world has become technology driven where social networking is the new avenue for sellers to extend their campaigns to an enormous population of consumers.

Social Media Marketing is the new approach to communicate with the consumers. It is a well-known fact that method of communication is being 
Dokuz Eylül Üniversitesi İktisadi ve İdari Bilimler Fakültesi Dergisi Cilt:33, Sayl:1, Yll:2018, ss. 217-234

shifted from one way to two way through technology. Social networking sites are the rising platform for marketers to target their potential customers.

Firms can get insights of the users of Social Networking Sites (SNS) by investigating SNS users for marketing purpose. In order to observe integration level of social networking sites into the lives of users, researchers have attempted to cultivate measures to social media use intensity (Maree, 2017).

\section{LITERATURE REVIEW}

Flagler (2011) argued that social media marketing should progressively be executed into the marketing plans of a firm instead of being considered as a replacement. He further stated that inclusion of social media marketing with other marketing tools will lead to improved results for the companies.

Chen (2011) concluded in his study that there is considerable amount of evidence that customer's attitude towards a product is or a brand is affected by the online word of mouth. Chen (2011) further explained that many scholars are now paying attention and researching the influence of social media on products consumer decision-making, product sales and sales estimates. Not only this, but also the impact of social media marketing to the existing marketing strategy of the company.

The importance of social media can be realized with the low cost interactive and immediate communication between the consumers and the companies. In this era, internet communities, blogs and social media networks have become an important part of people's life. Their importance can be judged from the fact that these mediums act like an alternative tools of communications, which support the existing relationships and activities enriching the experience of 


\section{S.I.AKBAR - E.ÖZGÜL}

users. In addition, augmented social media use has become a platform for brand nurturing which eventually affects the consumer's purchase decision (Miller, Fabian and Lin (2009) in Kim and Ko (2010)).

Chu (2011) elaborated in his study that engagement and group participation with online ads needs a high level of personal information and the reason behind this is that users openly disclose their connections with groups on Facebook and products and brands are automatically promoted when they share the ads with their friends. In Chu's (2011) words “Facebook groups provide channels that consumers deem useful when seeking self-status in a product category, as does passing on viral content about brands to their social contacts" Chu (2011) also discovered that Facebook group members have more auspicious attitude for advertising and social media. Users who carry positive image towards advertising are more prospective to join Facebook group of a retailer or a brand for their promotional campaigns and messages.

The emergence of social media, also known as consumer generated media has significantly changed the communication strategies and tools used to contact with customers. This type of media can be described as "new sources of online information that are created, initiated, circulated and used by consumers intent on educating each other about products, brands, services, personalities, and issues" (Blackshaw and Nazzaro, 2004).

Social Media can also be defined as "a group of Internet-based applications that build on the ideological and technological foundations of Web 2.0 and that allows the creation and exchange of user-generated content” (Belch, 2015)

It is the advent of internet based social media due to which now possible that one person can communicate with thousands of people and provide them 
Dokuz Eylül Üniversitesi İktisadi ve İdari Bilimler Fakültesi Dergisi

Cilt:33, Sayl:1, Yll:2018, ss. 217-234

information regarding products, brands and companies. This is the reason that the communication among consumers is given importance in this era (Mangold \& Faulds, 2009).

Mangold and Faulds, (2009) stated several authors proposed that one of the excellent forms of communication between the company and customers is social media marketing. Companies can use social media to their advantage to reach consumers in receptive ways. They further elaborated that social media has huge range of online word of mouth platforms which include discussion boards sponsored by the company, blogs, consumer to consumer email, chat rooms, consumer rating websites for products and services, moblogs, internet discussion forums and boards and social media websites.

\subsection{Social Media Use}

Previously, frequency of use and duration have been used as measure for social media use. Maree (2017) discussed Orosz et al. (2015) findings in her study and stated that previous Facebook research encompasses scales concentrated on number of friends, time spent on social media, group memberships and some other activities on Facebook. However, such kind of activities are not adequate to indicate Facebook usage (Ellison et al., 2007 in Maree, 2017). This argument was also backed by Jenkins-Guarnieri et al. (2013). They also agreed to the argument that frequency scales are not sufficient as proof of people's social media incorporation in their lives.

\subsection{Brand Awareness}

Aaker (1996) defined brand awareness as the ability of a consumer to recall and identify or recognize a brand in various situations. He elaborated that brand 


\section{S.I.AKBAR - E.ÖZGÜL}

awareness has two main determinants; brand recall and brand recognition. Brand recall refers to recalling of name of a brand exactly while seeing a product category. On the other hand, brand recognition refers to the ability of consumers to identify a brand when given a clue about the brand. In other words, telling a brand name correctly if they see or hear any clue about it.

Furthermore, Hoeffler and Keller (2002) identified that brand awareness can be illustrated from two determinants; depth and width. Depth answers the question "how to make consumers recall or identify brand in an easy manner", while width refers to "when consumers purchase a product, a specific brand name comes to their minds at once”. In case, a product has depth and width simultaneously, it means consumer will think of a particular brand while buying a product. This will lead to the conclusion that the brand awareness of that specific product is high. Apart from this, Keller (1993) stated that brand awareness affects purchase decision via brand association. He added that a positive image of a brand eventually helps in marketing activities.

The previous studies have discussed mainly about the communication of companies with consumers, however, the gap in the study is the question that does the social media can actually change the knowledge of consumers about brands. Do consumers really give importance to social media advertisements or not. Does social media marketing actually influences the awareness of consumers or not (Edelman, 2010 in Hutter, Hautz, Dennhardt and Füller, 2013).

\section{RESEARCH METHODOLOGY}

Objective of this research is to study the impact of social media activities of social networking sites members; more specifically Facebook members, on the 
Dokuz Eylül Üniversitesi İktisadi ve İdari Bilimler Fakültesi Dergisi

Cilt:33, Sayl:1, Yll:2018, ss. 217-234

brand awareness. The study mainly focuses on finding the effectiveness of social media marketing. It aims to find how successful social media marketing is for making brand awareness in potential customers.

\subsection{Research Model and Hypothesis}

The model shows the independent variable i.e. social media usage which has two dimensions; social integration and emotional connection (SIEC) and integration into social routines (ISR). This independent variable directly impacts the dependent variable i.e. brand awareness. Figure 1 shows the diagram of the research model.

Social Media Usage

Activities

Dimentions:

SIEC

$I S R$

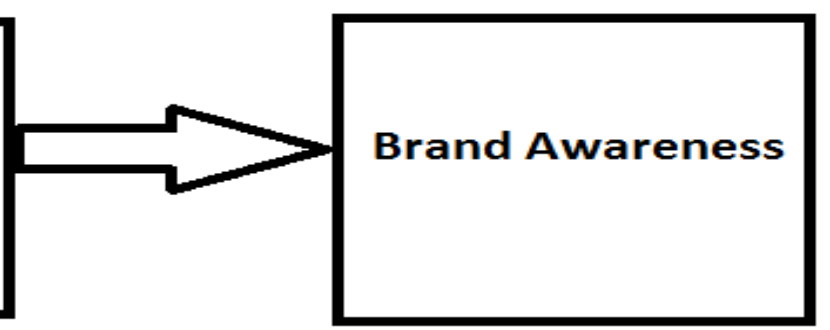

Figure 1. Research Model

The independent variable i.e. social media activities of this study has two dimensions; SIEC and ISR. Hence the study will try to find out if social media positively impacts brand awareness or not. The study hypotheses are given below:

H1 = SIEC is positively related to Brand Awareness

H2= ISR is positively related to Brand Awareness

For the social media usage to completely influence brand awareness, both the dimensions of Social Media Usage should impact brand awareness 


\section{S.I.AKBAR - E.ÖZGÜL}

positively. This is the reason that both hypothesis assume a positive impact on brand awareness. This assumption is taken by considering the previous researches discussed in the literature review including studies of Mangold and Faulds, (2009), Chu, (2011), Flaglar, (2011) and Bruhn, Schoenmueller and Schäfer, (2012).

The research focuses to study the behavior of young consumers who come across ads of different products on social media. The research focuses on university students and study is conducted on small scale, therefore population for this research is for university students. Since Dokuz Eylul University is a large university, due to lack of time and resources, Dokuz Eylül University Dokuzcesmeler campus students are taken as a sample for the university. Another reason for selection of Dokuzcesmeler campus as a sample of the research is the convenience of data collection keeping in mind the time and resource constraints. 100 students were selected on the basis of availability for data collection of the research. Primary data was collected by questionnaire survey method. Questionnaire was created and administered in the Dokuzcesmeler Campus area.

The questionnaire was first tested for validity and reliability. After the factor analysis, regression was run between the dimensions of social media usage and brand awareness to find the impact of social media usage on brand awareness.

\subsection{Explanation of Scales}

Since the study aim to explain the impact of social media activities of social networking sites members, two scales are used in the questionnaire. To measure social media integration, Social Media Use Integration Scale (SMUIS) which was developed by Jenkins-Guarnieri et al. (2013) was used. It is a ten items 
Dokuz Eylül Üniversitesi İktisadi ve İdari Bilimler Fakültesi Dergisi

Cilt:33, Sayl:1, Yll:2018, ss. 217-234

Likert scale comprising two social media use dimensions, which are mirrored in two sub-scales. Those two dimensions are Social Integration and Emotional Connection (SIEC) and Integration into Social Routines (ISR). SIEC is signified by 6 items:

1. I feel disconnected from friends when I have not logged into Facebook

2. I would like it if everyone used Facebook to communicate

3. I would be disappointed if I could not use Facebook at all

4. I get upset when I can’t log on to Facebook

5. I prefer to communicate with others mainly through Facebook

6. Facebook plays an important role in my social relationships

On the other hand, four items represent ISR dimension:

1. I enjoy checking my Facebook account

2. I don’t like to use Facebook (should be reverse scored)

3. Using Facebook is part of my everyday routine

4. I respond to content that others share using Facebook

The second scale aims to measure consumer awareness about the brands. This study used the scale of Aaker (1996) to measure the brand awareness. It consists of 4 items encompassing recognition, recall, top-of-the-mind and brand knowledge. It is a seven point Likert scale. The items are as follows:

1. The decision-makers of our potential customers have heard of our brand.

2. The decision-makers among our potential customers recall our brand name immediately when they think of our product category.

3. Our brand is often at the top of the minds of the decision-makers in potential customer firms when they think of our product category. 


\section{S.I.AKBAR - E.ÖZGÜL}

4. The decision-makers can clearly relate our brand to a certain product category.

\subsection{Data Analysis}

\subsubsection{Demographics}

Out of total 100 respondents, 56 were male and 44 were female. Similarly, most of the students belonged to age group of 18-24 and were bachelors students. The Table 1 shows the number of participants from each age group with the current level of education.

Table 1. Age and Education Distribution

\begin{tabular}{|c|c|c|c|c|c|}
\hline & \multicolumn{3}{|c|}{ Education } & \multirow{3}{*}{$\begin{array}{c}\text { Total } \\
58\end{array}$} \\
\hline & & \multirow{2}{*}{$\begin{array}{c}\text { Bachelors } \\
46\end{array}$} & \multirow{2}{*}{$\begin{array}{c}\text { Masters } \\
12\end{array}$} & \multirow{2}{*}{$\begin{array}{c}\text { Doctorate/Ph.D. and above } \\
0\end{array}$} & \\
\hline \multirow[t]{3}{*}{ Age } & $18-24$ & & & & \\
\hline & $25-33$ & 10 & 27 & 2 & 39 \\
\hline & $34-42$ & 0 & 3 & 0 & 3 \\
\hline \multicolumn{2}{|c|}{ Total } & 56 & 42 & 2 & 100 \\
\hline
\end{tabular}

\subsubsection{Normality and Validity of Scales}

The data was first put into normality tests to find out that if the collected data is normally distributed or not. The results of Kolmogorov-Smirnov significance and Shapiro-Wilk significance (Table 2) illustrate that all the items have 0.000 significance which is below the level of 0.05 . For a data to be normally distributed, this value should be more than 0.05 . Hence it is concluded that the data is not normally distributed.

Descriptive table shows the skewness and Kurtosis values of all the fourteen items. It can be witnessed from the table that all the items have their values near 
Dokuz Eylül Üniversitesi İktisadi ve İdari Bilimler Fakültesi Dergisi

Cilt:33, Sayl:1, Yll:2018, ss. 217-234

zero which is a good sign. It shows less level of skewness of data from normal distribution.

Factor analysis was conducted for both the scales of the questionnaire separately. Firstly, the results of SMUI scale are discussed here. The item sample "I do not like Facebook" was reversed from 1 to 5 as 5 to 1 to get normal results.

KMO shows the adequacy of the sample which is 0.863 for this scale. It means the sample is adequate for the tests. Bartlett's sig is 0.000 which is less than 0.05. It is an evidence that the responses from the audience are valid and suitable for the study.

Table 2. KMO and Bartlett's Test

\begin{tabular}{|l|l|}
\hline Kaiser-Meyer-Olkin Measure of Sampling Adequacy. & .863 \\
\hline Bartlett's Test of Sphericity: Sig & 0.000 \\
\hline
\end{tabular}

In the total variance explained table, it showed that this scale will be pursued under two factors. The total cumulative variance was 65.221, showing the percentage of explanation accounted by the two factors together. The table divided the variables into 2 components having percentage of square loadings of 34.545 and 30.068 percent respectively.

Table 3.Total Variance Explained

\begin{tabular}{|c|c|c|}
\hline \multicolumn{3}{|c|}{ Rotation Sums of Squared Loadings } \\
\hline Components & \% Variance & Cumulative \% \\
\hline Component 1 & 34.545 & 34.545 \\
\hline Component 2 & 30.068 & 65.221 \\
\hline
\end{tabular}

Rotation component matrix shows relation of item questions with the previously defined three components in the Total Variance Explained table. 


\section{S.I.AKBAR - E.ÖZGÜL}

This table classifies all the ten item questions into two components. The item questions for Social Integration and Emotional connection (SIEC) are classified into component 1, Integration into Social Routines (ISR) into component 2. However, the item questions "I get upset when I can't log on to Facebook" (Upset) had strong and close value in both the components i.e. 0.569 and 0.534. Similarly, "I would be disappointed if I could not use Facebook at all" (Disappointment) had value of 0.558 and 0.567 in component 1 and 2 respectively, hence to avoid being calculated in both the components, "I would be disappointed if I could not use Facebook at all" was removed first from the scale based on lesser value in communality value. The final Cumulative Variance percentage was improved. The updated values are given in the Table 4.

Table 4. KMO and Bartlett's Test

\begin{tabular}{|c|c|}
\hline Kaiser-Meyer-Olkin Measure of Sampling Adequacy. & .858 \\
\hline Bartlett's Test of Sphericity: Sig & 0.000 \\
\hline Final Cumulative Variance percentage & 66.022 \\
\hline
\end{tabular}

The final table of Rotated Component Matrix i.e. Table 5 is given below with item questions categorized in their respective components.

Table 5. Rotated Component Matrix

\begin{tabular}{|l|c|c|}
\hline \multicolumn{1}{|c|}{ Item Questions } & \multicolumn{2}{c|}{ Component } \\
\cline { 2 - 3 } & SIER & .852 \\
\hline I prefer to communicate with others mainly through Facebook & .745 & \\
\hline Facebook plays an important role in my social relationships & .710 & \\
\hline I would like it if everyone used Facebook to communicate & .671 & \\
\hline $\begin{array}{l}\text { I feel disconnected from friends when I have not logged into } \\
\text { Facebook }\end{array}$ & & \\
\hline
\end{tabular}


Dokuz Eylül Üniversitesi İktisadi ve İdari Bilimler Fakültesi Dergisi Cilt:33, Sayı:1, Yıl:2018, ss. 217-234

\begin{tabular}{|l|c|c|}
\hline I respond to content that others share using Facebook & .608 & \\
\hline I get upset when I cannot log on to Facebook & .563 & \\
\hline Using Facebook is part of my everyday routine & & .813 \\
\hline I enjoy checking my Facebook account & & .753 \\
\hline I don't like Facebook (Reverse) & & .830 \\
\hline
\end{tabular}

The KMO value for Brand Awareness scale comes out to be 0.791 with a Bartlett's sig of 0.00. Hence the scale is valid. Its Total Variance Explained in the results table shows the cumulative percentage of $72.421 \%$, which means the scale explains $72.421 \%$ of the model. It has single component in the factor analysis.

Reliability for the items of SIEC activities variable comes out to be consistent. The Cronbach's Alpha value is 0.854 considering all the 6 items of the SIEC. The reliability for ISR was 0.800 taking into account all the 3 items given in Table 6.

Similarly, Reliability for Brand awareness came out to be internally consistent as well. The Cronbach's Aplha for Brand Awareness is 0.872 out of its 4 items. This shows strong level of reliability for the data

Table 6. Reliability Statistics

\begin{tabular}{|c|c|c|}
\hline Variable & Cronbach's Alpha & No. of Items \\
\hline SIEC & 0.854 & 3 \\
\hline ISR & 0.800 & 4 \\
\hline BA & 0.872 & 3 \\
\hline
\end{tabular}

\subsubsection{Regression Analysis Results}

Regression analysis was applied to gauge out the relationship between variables i.e. SIEC and ISR as independent variables and BA as dependent 


\section{S.I.AKBAR - E.ÖZGÜL}

variable. It is also necessary to question the existence of certain conditions. In this context, normality and multi-collinearity analyzes of the variables to be used in the model have been made and it has been determined that there are no problems with the preconditions of the regression analysis. The results obtained are summarized in the table below.

In table the value of $\mathrm{R}$ square is 0.341 which illustrates that $34.1 \%$ variation of Brand Awareness is explain by independent variable i.e. Social media activities. R square also demonstrates the fitness of the model. The result in the table 6 exhibits the output of the ANOVA analysis to check the statistical significance in regression. The significance value is 0.000 (i.e., $\mathrm{p}=0.000$ ), which is below 0.05 hence elucidating the statistical significance of the regression.

Table 7. Regression Analysis Results

\begin{tabular}{|l|c|c|}
\hline & $\boldsymbol{\beta}$ & $\mathbf{t}$ \\
\hline Constant & -1.216 & $7,554 * *$ \\
\hline SIEC (social integration and emotional connection) &, 412 & $3,843^{* *}$ \\
\hline ISR (Integration into social routines) &, 228 & $2,125 *$ \\
\hline $\mathrm{R}=0,584 \mathrm{R}^{2}=, 341 ;$ St. Error=,820; $\mathrm{F}=25,101^{*} ; \mathrm{p}=, 001$ & \\
\hline$* * \mathrm{p}<, 01 ; * \mathrm{p}<, 05$ & & \\
\hline
\end{tabular}

Coefficients illustrates the multiple regression analysis results. The social media activities have two dimensions; one is social integration and emotional connection (SIEC) and the coefficient value of SIEC is 0.412 indicating that there is a direct and positive relationship with brand awareness. It demonstrates that whenever there is one percent increase in the SIEC activity, it leads to $41.2 \%$ increase in the brand awareness. The results also show that this relationship is statistically significant i.e., $0.000 \mathrm{p}$-value is less than 0.05 . Therefore, the H1 is accepted. 
Dokuz Eylül Üniversitesi İktisadi ve İdari Bilimler Fakültesi Dergisi Cilt:33, Sayl:1, Yll:2018, ss. 217-234

The second dimension of independent variable of this study i.e. Integration into Social Routines (ISR) has also a significant and positive effect on brand awareness. The computed value of ISR elaborates that if one percent rise in the ISR is observed, it will lead to $22.8 \%$ rise in brand awareness. Its significance value is recorded as 0.036 which is also less than 0.05 , hence considered acceptable. Consequently, the $\mathrm{H} 2$ is accepted too. The constant value is insignificant. The equation for this study is given below:

\section{BA $=-1.216+0.412($ SIEC $)+0.228($ ISR $)$}

\section{CONCLUSION}

The study inspected the relation between social media usage and brand awareness. Social media activities were measured through two dimensions; SIEC and ISR. The results of statistical tests suggest that social media usage has a positive influence on brand awareness of consumers. Both the dimensions were positively related to brand awareness. It can be concluded from the study that social media marketing can be handy in educating potential consumers about brands. Formerly, researches have been done to measure social media marketing effectiveness. Kim and Ko (2010) also conducted a similar research to find effectiveness of social media marketing. They came to the conclusion that social media marketing is an effective medium for marketing for luxury brands. DEI worldwide (2008) discussed in Kim and Ko’s study (2010) reports that purchase decision has strong relation with social media sites. Consumers refer to social media to get information about products and then share that information with others. Hutter et. Al. (2013) analyzed the impact of social media activities of brand and participants' social media involvement on the 


\section{S.I.AKBAR - E.ÖZGÜL}

purchase decision of consumers. Their findings illustrate that if consumers are engaged with the fan page of a brand on Facebook, it positively affects brand awareness of consumers. They also concluded that social media is a strong source of word of mouth promotion.

This study also implies similar findings and answers the research questions by showing positive relation between social media usage and brand awareness. It suggests that the more consumers engage in social media, the more they get informed about brands. Social media marketing can be handy in recalling brands when consumers make purchases.

\subsection{Limitations and Implications}

The research is conducted on small scale in Dokuz Eylul University, Izmir, Turkey. The sample size is 100 respondents. Therefore, results cannot be generalized. This study can be improved by encompassing a bigger sample and targeting a bigger population to test the relationship between social media tools and brand awareness. Since the sample was a university, all of the respondents were students and most of them belonged to the age group between 18 and 24 . The study can be further investigated by including more percentage other age groups as well. Similarly, the social media incorporated in this study was Facebook. Other forms of social media can also be incorporated to improve the results of the study.

\section{REFERENCES}

AAKER, D. A. (1996). Measuring brand equity across products and markets. California management review, 38(3), 102.

BELCH, G. E., \& BELCH, M. A. (2004). Advertising and Promotion: An Integrated Marketing Communications Perspective, (6 Th. New York: NY: McGraw-Hill. 
BLACKSHAW, P., \& NAZZARO, M. (2004). Consumer-Generated Media (CGM) 101: Word-of-mouth in the age of the Web-fortified consumer. Retrieved July 25, 2008.

BRENNAN, B. E. R. N. I. E., SCHAFER, L. O. R. I. (2010). How Retailers Engage Consumers with Social Media and Mobility, (Vol. 39). John Wiley \& Sons.

CHEN, Y., Fay, S., WANG, Q. (2011). The role of marketing in social media: How online consumer reviews evolve. Journal of Interactive Marketing, 25(2), 85-94.

CHU, S. C. (2011). Viral advertising in social media: Participation in Facebook groups and responses among college-aged users. Journal of interactive advertising, 12(1), 30-43.

FLAGLER, R. (2011). Are You Social? Marketing Your Business with Facebook and Twitter. New York Amsterdam News, 7, 6.

GOYETTE, I., RICARD, L., BERGERON, J., MARTICOTTE, F. (2010). e-W OM Scale: word- of-mouth measurement scale for e-services context. Canadian Journal of Administrative Sciences/Revue Canadienne des Sciences de l'Administration, 27(1), 5-23.

HOEFFLER, S., \& KELLER, K. L. (2002). Building brand equity through corporate societal marketing. Journal of Public Policy \& Marketing, 21(1), 7889.

HUTTER, K., HAUTZ, J., DENNHARDT, S., FÜLLER, J. (2013). The impact of user interactions in social media on brand awareness and purchase intention: the case of MINI on Facebook. Journal of Product \& Brand Management, 22(5/6), 342-351.

JENKINS-GUARNIERI, M. A., WRIGHT, S. L., JOHNSON, B. (2013). Development and validation of a social media use integration scale. Psychology of popular media culture, 2(1), 38. 


\section{S.I.AKBAR - E.ÖZGÜL}

KELLER, K. L. (1993). Conceptualizing, measuring, and managing customer-based brand equity. The Journal of Marketing, 1-22.

KIM, A. J., \& KO, E. (2010). Impacts of luxury fashion brand's social media marketing on customer relationship and purchase intention. Journal of Global Fashion Marketing, 1(3), 164-171.

MANGOLD, W. G., FAULDS, D. J. (2009). Social media: The new hybrid element of the promotion mix. Business horizons, 52(4), 357-365.

MAREE, T. (2017). The Social Media Use Integration Scale: Toward Reliability and Validity. International Journal of Human-Computer Interaction, 33(12), 963-972. 